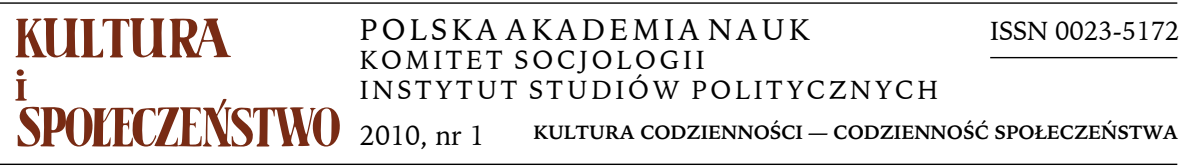

MARTA SKOWROŃSKA

Uniwersytet im. Adama Mickiewicza w Poznaniu

\title{
KOMFORT, CZYLI CO OZNACZA MIESZKAĆ DOBRZE
}

Angielskie słowo comfort można tłumaczyć dwojako. Po pierwsze, oznacza ono pociechę i wsparcie - to najstarsze rozumienie Anglicy zaczerpnęli $z$ francuskiego conforter („posilać, pokrzepiać”), francuskie słowo z kolei genezę ma w łacińskim conforatere: „umacniać, wzmacniać”. Mniej więcej do XVIII-XIX wieku było to znaczenie jedyne (poza teologia, gdzie tym mianem określano Ducha Świętego i Zbawiciela, oraz prawem, gdzie określenia comforter używano w odniesieniu do współzbrodniarza, a wiec osoby będącej wsparciem dla przestępcy; zob. Rybczyński 1996, s. 23-28). Później jednak upowszechniło się drugie znaczenie - uczucie przyjemności i zadowolenia, zarówno co do cech fizycznych otoczenia, jak i rzeczy, które to zadowolenie przynoszą. Zarówno Elizabeth Shove, zajmująca się tematyką komfortu, jak i inny znawca tego tematu, kanadyjski historyk John E. Crowley, piszą o komforcie jako satysfakcji czy zadowoleniu wynikającym $z$ „relacji między człowiekiem a jego fizycznym otoczeniem" (Crowley 1999, s. 749; Shove 2003, s. 24). Polskie słowo „komfort” nawiązuje do tego właśnie rozumienia, oznacza bowiem „zespół urządzeń, warunków, zapewniający wygodę i odpowiadający w pełni wymaganiom estetyki” czy „ogół warunków zewnętrznych zapewniających człowiekowi wygodę, odznaczających się dostatkiem i elegancją", albo „stan zaspokojenia potrzeb fizycznych i psychicznych oraz braku kłopotów".

To nowe znaczenie słowa „komfort” najczęściej odnoszono do miejsca zamieszkania. Przykładów dostarcza brytyjska literatura tamtego czasu; na początku XIX wieku angielski poeta Robert Southey, pisząc o swoim kraju z punktu widzenia cudzoziemca, jako Hiszpan o nazwisku Don Manuel Alvarez

Adres do korespondencji: Instytut Socjologii UAM, ul. Szamarzewskiego 89, 60-825 Poznań. 
Espriella (Crowley 1999, s. 749) tak przedstawił ówczesne podejście Anglików do komfortu:

„Istnieją dwa słowa w ich języku, które są dla nich źródłem dumy i których nie sposób przetłumaczyć. Jedno to dom (home), przez które Anglik rozumie budynek mieszkalny (house)... Drugie to komfort; oznacza ono wszystkie przyjemności i przywileje, jakie daje dom; tu muszę przyznać, że ci dumni wyspiarze mają powody dla swej dumy. W swoich stosunkach społecznych i sposobie życia mają przyjemności, o jakich nam się nie śniło" (cyt. za Crowley 1999, s. 749).

Pojawienie się $\mathrm{w}$ języku nowego znaczenia istniejącego słowa musi wskazywać na potrzebę wyrażenia określonego pojęcia czy idei, która wcześniej nie istniała i tym samym na zmiany, jakie zaszły w rzeczywistości społecznej, świadomości ludzkiej czy sposobach działania. W tym przypadku nowe znaczenie słowa „komfort” wiąże się $z$ pewnymi zmianami w rozumieniu domu i domowości (w przytoczonym cytacie zakres tej zmiany wyrażają słowa „o jakich się nie śniło"), jakie następowały mniej więcej od XVIII-XIX stulecia najpierw w Anglii, a później także w całej Europie. Zmianom tym najlepiej jest się przyjrzeć, analizując szczegółowo, czym jest komfort dzisiaj, a więc jakie są „części składowe" jego definicji, i jaki był ich historyczny rozwój.

Szczegółowa definicja komfortu nie jest prosta, ponieważ nie jest to kategoria ani obiektywna, ani też mierzalna. „Zadowolenie wynikające z relacji między człowiekiem a jego fizycznym otoczeniem" to ogólne sformułowanie, które może oznaczać co innego dla różnych ludzi, na co wskazuje część badań poświęconych satysfakcji z miejsca zamieszkania (Madigan, Munro 1996; Woodward 2003; Ureta 2007). Dla niektórych komfort może sprowadzać się do wrażenia, że „każdy przedmiot jest na swoim miejscu” albo że kolory mebli, ścian i dodatków stanowią harmonijną całość; dla innych wiąże się z zadowoleniem, że można rozsiąść się w miękkim, wygodnym fotelu przy kominku, a jeszcze dla innych $z$ tym, że chociaż miejsce zamieszkania nie jest ani ładne, ani wygodne, to jednak daje możliwość ucieczki od świata w prywatną, intymną, własną przestrzeń. Próby kwantyfikowania komfortu i określenia, czym jest wzorcowo komfortowe mieszkanie, często więc spotykały się z niepowodzeniem. Kiedy na przykład na początku XX wieku lekarze mieli stwierdzić, jaka jest najdogodniejsza pozycja dla ciała ludzkiego, by według wypracowanego w ten sposób wzorca projektanci mogli stworzyć idealne wnętrza, okazało się, że wyniki badań nie pokrywały się z opiniami ludzi o tym, co jest komfortowe, gdyż obok czynników obiektywnych, takich jak dopasowanie przedmiotu do kształtu ciała ludzkiego, istotną rolę odgrywają czynniki kulturowe, wyobrażenia ludzi żyjących w określonym miejscu i czasie o tym, co stanowi dobre wnętrze, a także czynniki indywidualne - subiektywne przekonania czy przyzwyczajenia (zob. Shove 2003, s. 25).

Komfort nie jest więc pojęciem obiektywnym, ale też nie całkowicie subiektywnym i idiosynkratycznym, a można raczej wyróżnić wiele możliwych 
elementów, z których ludzie tworzą różnego typu konfiguracje. Istotne mogą więc być na przykład: (1) wygoda ciała, fizyczny odpoczynek, wyrażający się nie tylko w zaspokojeniu potrzeby ciepła, światła i odpowiedniej przestrzeni, ale też (2) „zgranie”, zharmonizowanie ciała z przedmiotami, oznaczające powtarzalność i płynność ruchów, pewność, stabilność wynikającą z pamięci ciała o tym, jak się poruszać, (3) dogodność związana z dostępnością przedmiotów ułatwiających wykonywanie różnych czynności, (4) urządzenie wnętrza zgodnie $z$ indywidualnymi kryteriami piękna, (5) organizacja przedmiotów $\mathrm{w}$ przestrzeni zgodna $\mathrm{z}$ własną koncepcją porządku i ładu, a także czystości, (6) ogólnie rozumiane poczucie „bycia u siebie”, związane zarówno z poczuciem bezpieczeństwa wynikającym ze schronienia przed niebezpieczeństwami zewnętrznego świata, jak i „naznaczenia” przestrzeni osobowością, stylem życia, wspomnieniami.

Te możliwe rozumienia komfortu najogólniej można by objąć takimi kategoriami, jak prywatność i intymność, a także związana $z$ tym $z$ jednej strony ekspresja „ja” i „bycie sobą”, z drugiej przytulność i rodzinne ciepło, a także wygoda i funkcjonalność.

\section{PRYWATNOŚĆ}

Jak już wspomniałam, nowe znaczenie słowa „komfort” pojawiło się w XVIII-XIX wieku, co niewątpliwie wiąże się z tym, że w owym czasie centralną kategorią $\mathrm{w}$ odniesieniu do procesu zamieszkiwania stawała się prywatność. Trudno byłoby oczywiście wyznaczyć, kiedy koncepcja prywatności pojawiła się w kulturze europejskiej. Prywatność to sfera zbyt indywidualna i heterogeniczna, by była polem do konstrukcji wielkich historycznych narracji, dlatego historia nie wskazuje nam konkretnych dat (zob. Rice 2007). Jeśli jednak prywatności poszukamy w wyglądzie i charakterze gospodarstw domowych, to można stwierdzić, że w XVIII, a tym bardziej XIX wieku dom coraz bardziej tracił charakter publiczny, a zaczynał być traktowany jako przestrzeń prywatna (Ariès 1995; de Mare 2006; Malconado 2006; Rice 2007; Hollows 2008; Munro, Madigan 2006). W tym procesie można wyróżnić dwie fazy. Pierwsza polegała na wzroście wyizolowania domu z zewnętrznego otoczenia; dom stawał się coraz bardziej zamknięty dla obcych i zaczął pełnić rolę bezpiecznej, przytulnej twierdzy, w której można schronić się przed światem. Druga faza to proces prywatyzowania przestrzeni wewnątrz domu, a więc postępująca dyferencjacja i indywidualizacja przestrzeni, w której poszczególni domownicy zaczynali mieć prawo do indywidualnie, nie rodzinnie, pojętej prywatności.

\section{Izolacja od świata}

W średniowieczu brakowało zasadniczego rozgraniczenia między prywatnym a publicznym. Życie i praca były połączone nie tylko w domu wiejskim, 
ale także na przykład w typowym czternastowiecznym domu mieszczańskim, który nie składał się z pełniących różne funkcje pomieszczeń, ale z dużej komnaty $\mathrm{z}$ niewielką liczbą mebli, których funkcja zmieniała się $\mathrm{w}$ zależności od potrzeby, nierzadko ustawiano w tej sali również łoża. Gromadzili się tam nie tylko domownicy, ale i służba, goście, klientela i ulubione psy (Kowecka 1975, s. 239; Madanipour 2003, s. 68). Brakowało wówczas publicznych miejsc spotkań, w rodzaju hotelu czy restauracji. Mieszkanie i praca znajdujące się w jednym miejscu, otwartym na przybyszów, nie sprzyjały prywatności rodziny. Dopiero dom uwolniony od funkcji warsztatu pracy, zamknięty dla obcych, mógł być centrum życia prywatnego. Industrializacja i masowość produkcji mieszkań pozwalała ponadto na przestrzenne wydzielenie rodziny nuklearnej. Staranne oddzielenie dwu sfer - publicznej i prywatnej — widoczne jest również w strukturyzowaniu domowej przestrzeni. Coraz częściej miejsce odpoczynku domowników było umiejscowione w tylnej części mieszkania, do której mieli dostęp tylko mieszkańcy i służba (por. Ariès 1995; Ferenc 2004; Sienicki 1962; Kałwa 2004; Rybczyński 1996). Najszybciej zmiany takie następowały w Anglii, gdzie w drugiej połowie XIX wieku sypialnia staje się miejscem całkowicie prywatnym, osoby spoza domu mają do niej zakaz wstępu. Angielski dwór nie był już „jak otwarty średniowieczny dom, tylko zamknięty świat, do którego wpuszczano wybranych" (Rybczyński 1996, s. 111). Ukształtowanie się takich wzorców domowości w Anglii, a więc koncentracja na rodzinie, zwiększenie rodzinnej intymności, złagodzenie formalności stosunków małżeńskich, nastąpiło w okresie rządów królowej Wiktorii. Małżeństwo angielskiej królowej z księciem Albertem miało bardzo nowoczesny charakter; królewska para dzieliła sypialnię, spędzała wspólnie wolny czas i koncentrowała się na wychowywaniu dzieci. Jej rodzina miała być wzorem życia rodzinnego - nie tylko dla arystokracji, ale i mieszczan. Jest to okres rozkwitu kultury mieszczańskiej i jej dominacji nad kulturą dworską (Starkey 2006), także we Francji, zwłaszcza gdy w latach pięćdziesiątych XIX wieku monarchia ustąpiła tam republice. Model prywatnego życia rodzinnego początkowo występował przede wszystkim wśród bogatego mieszczaństwa, stopniowo jednak przenosił się również do niższych warstw (Madanipour 2003, s. 70). Troska o prywatność uwidaczniała się później w projektach modelowych mieszkań dla klasy robotniczej, gdzie sypialnie oddzielone były od pokoju dziennego (Madanipour 2003, s. 76).

Postępująca separacja sfery publicznej i prywatnej, niezbędna dla ukształtowania się współczesnego pojęcia komfortu, stała się też obiektem krytyki. Podziałowi na prywatne i publiczne zarzuca się bowiem umocnienie podziału na sferę męską i kobieca, a także stabilizowanie tradycyjnych wartości (Cieraad 2006; Hollows 2008; Maldonado 1996; Madigan, Munro, 1999; Munro, Madigan 2006; Rice 2007; Heynen 2005; Baydar 2005; de Mare 2006; Laermans, Meulders 2006). Krytyka wywodząca się z feminizmu wypływa z przekonania, że koncepcja prywatności umacnia rolę kobiety jako strażniczki ogniska domowego. Siedemnastowieczny holenderski poeta Jacob Cats pisze na przykład 
o pani domu jako „najlepszym meblu” (the best piece of furniture), którego zadaniem jest utrzymanie domu w ryzach (zob. de Mare 2006, s. 20). Dobrochna Kałwa zaś tak opisuje polskie domy mieszczańskie: „Naruszenie zasad urządzania salonu narażało właścicielkę nie tylko na zarzut braku gustu, ale także na opinię słabej lub złej gospodyni. Dlatego każda pani dbała, by pokój był utrzymywany w czystości [...] meble zaś i wystrój wnętrza zapewniały domownikom i gościom komfort i przyjemne wrażenia estetyczne" (Kałwa 2004, s. 257). Wiedza praktyczna, jaką dysponowała kobieta, miała sprawić, by wszystkie działania w obrębie gospodarstwa domowego przebiegały gładko. Jedynie dzięki jej dobrej opiece dom i rodzina mogły trwać w harmonii (de Mare 2006, s. 20). Podział ten stabilizowało - jak pisze Joanne Hollows (2008, s. 15) - utożsamienie sfery publicznej $z$ chaosem, brudem, rozkładem moralnym i zaburzeniem tradycyjnego porządku, skontrastowanymi z harmonijną i cnotliwą egzystencją domową. Rozdział publiczne-męskie, prywatne-kobiece umacniało przekonanie o niebezpieczeństwie sfery publicznej, o tym, że jest ona brudna, zakażona i zła. Kobiety mogły się więc po niej poruszać tylko w wyznaczonych miejscach i w dzień. Na przykład tytułowa bohaterka powieści Henry’ego Jamesa Daisy Miller po tym jak spacerowała w nocy - i do tego z obcym mężczyzną — po oddalonych od domu terenach zapada na malarię, której zarazki krążą jakoby w niezdrowym powietrzu, i umiera. $Z$ kolei komfort związany z prywatnością i intymnością miał zagrażać męskości. Obawiano się, czy synowie wychowywani w cieple matczynej opieki będą dość męscy (Heynen 2005, s. 9).

Dziś coraz częściej podaje się $\mathrm{w}$ wątpliwość ścisłość omawianego podziału, przede wszystkim ze względu na „okablowanie” domu, a więc wkroczenie w przestrzeń domową na nieznaną dotychczas skalę mediów, a tym samym bliską obecność sfery publicznej. Krytyka ta jednak pomija fakt, że prywatyzacja sfery mieszkania $\mathrm{w}$ głównej mierze polegała nie na wyrugowaniu $z$ niego elementów sfery publicznej, lecz na wprowadzeniu wewnątrzdomowego podziału na sfery zarezerwowane dla mieszkańców (sypialnia) oraz te będące w zasięgu publicznego wzroku (salon). W tym sensie współczesny dom zasadniczo się nie różni. Poza tym obecność sfery publicznej zaznaczała się przez stosowanie się do wzorów urządzania domu, które już w XIX wieku były przekazywane medialnie (gazety, czasopisma, poradniki), choć trzeba przyznać, że z pewnością na mniejszą niż dziś skalę. Owo współczesne „okablowanie” może wprowadzać istotne zmiany, jeśli chodzi o ilość czasu spędzanego z rodziną i intensywność kontaktów. Na przykład telewizor - wcześniej zapewne radio - początkowo „złączył rodzinę”, gromadząc ją wokół odbiornika (Shove 2003, s. 54). Dzisiaj wiele gospodarstw domowych wyposażonych jest w kilka telewizorów, a także jeden bądź więcej komputerów, co oznacza, że członkowie rodziny mają skłonność do „rozpierzchania się” po pokojach.

Na koniec trzeba zauważyć, że nawet jeśli prywatność składa się na cząstkową definicję komfortu, to może się okazać, że dla niektórych inne aspekty są ważniejsze, aby w zajmowanej przestrzeni poczuli zadowolenie. Badania prze- 
prowadzone przez Instytut Wzornictwa Przemysłowego w połowie lat siedemdziesiątych w kilku miastach w Polsce (por. Górska, Szperlich 1985; Rębowska 1982) pokazały na przykład, że w rodzinach robotniczych i pochodzenia wiejskiego wciąż w wysokim stopniu obowiązuje wzór tradycyjny, sprzed stuleci. Typowa polska chata $\mathrm{w}$ okresie późnego średniowiecza składała się bowiem z jednej izby, do której przylegała spiżarnia, sień ze spichlerzem, gdzie na noc wpuszczano zwierzęta, oraz kuchni (Korczak 2004, s. 51; Zadrożyńska 1990, s. 37). Tym, co odróżniało dom szlachecki od chłopskiego, była druga izba w miejsce spichlerza. Jedna była używana na co dzień, drugą wykorzystywano od święta; stąd nazwa: biała izba — biała, bo nieosmolona od paleniska. Utrzymywanie prawie nieużywanego, reprezentacyjnego pomieszczenia było wyrazem luksusu i aspiracji. Ten sposób organizacji wnętrza, mianowicie podział na pomieszczenie służące celom reprezentacyjnym oraz dosłownie pojęty living room - pokój do życia, a więc połączenie salonu, jadalni i sypialni, okazał się niezwykle trwały. Jest to jeden z przykładów zróżnicowania pojęcia tego, czym jest satysfakcjonujące mieszkanie. Dla opisywanych rodzin posiadanie reprezentacyjnego pokoju „dla gości” było zgodne ze zinternalizowanym wzorcem „dobrego domu” do tego stopnia, że skłonni byli zredukować sferę prywatną w mieszkaniu.

\section{Przytulność i ciepło}

Intymność rodzinnego wnętrza blisko wiąże się też z kwestią przytulności i ciepła. Idea przytulności również ma korzenie w XIX wieku; wielu badaczy (zob. m.in. Rybczyński 1996; de Mare 2006; Rice 2007) uznaje, że nowa kultura mieszczańska promowała ideał ciepłego wnętrza jako stojący w opozycji do zimnych, formalnych kodów kultury dworskiej (jak wspomniano, w wiktoriańskiej Anglii nawet arystokracja skłaniała się bardziej właśnie ku mieszczańskiej domowości, nie ku dworskiej ceremonii). Przytulność była też interpretowana jako ucieczka od zimna, jakie przyniosła urbanizacja i industrializacja. Na płaszczyźnie materialnej przytulność odnosi się do praktyki dekorowania, ubierania, wypełniania i ozdabiania mieszkania różnymi przedmiotami, poduszkami, zasłonami, pamiątkami. Zarazem jednak przytulność to przyjemność bycia razem, doświadczania ciepła nieformalnej serdeczności, dobrego samopoczucia.

Przytulność doczekała się ostrej krytyki ze strony modernistycznych architektów oraz socjalistów, a także takich filozofów jak Walter Benjamin — słowem tych, którzy rozumieli nowoczesność jako społeczną równość, uważali, że jej celem jest proletaryzacja, emancypacja i uwolnienie człowieka od symbiotycznych i ograniczających struktur (van Herck 2005, s. 124-127). Le Corbusier swój atak na przytulne wnętrze uzasadniał potrzebą sprzeciwu wobec „sentymentalnej histerii”, Bruno Taut pisał, że praktyki „uprzytulniania wnętrza” są prymitywnym lub neurotycznym rytuałem, Hannes Meyer zaś że przytulność to coś, co powinno się mieć w sercu, a nie we wnętrzu (van Herck 2005, 
s. 124). Wspólne dla tych trzech argumentów było przekonanie, że mieszczański kult przytulności opiera się na arbitralnych, niesprawiedliwych relacjach władzy. Przekonanie to skutkowało promowaniem modelu niemieszczańskiej nowoczesności, której przyświecałyby ideały równości, emancypacji, racjonalności i czystości. Mieszczański dziewiętnastowieczny dom Benjamin określał jako muszlę, kokon wyściełany pluszem i aksamitem, który stanowi nie tylko schronienie, ale i pozwala na pozostawianie śladów, podczas gdy zewnętrzna rzeczywistość jest surowa i anonimowa. Odseparowanie i izolację traktował jako egocentryczny indywidualizm. Za ideał odpowiedni dla XX wieku uważał mieszkanie w domu ze szkła, co miało być wyrazem otwartości, socjalizacji i transparencji. Ściany mieszczańskiego domu stwarzają jedynie pozory, że sekretność to intymność, a egocentryczność to indywidualizm (van Herck 2005, s. 127).

\section{Indywidualność}

Prywatność może oznaczać zarówno odseparowanie mieszkania od wzroku obcych, jak i odseparowanie wewnątrz mieszkania poszczególnych członków rodziny od siebie. Prywatność jest więc nie tylko wyodrębnieniem się rodziny z szerszego kontekstu, odgrodzeniem domu od zewnętrznego świata, ale i oddzieleniem jednostki od rodziny. Jest warunkiem nie tylko konfrontacji domowej bezpiecznej fortecy z obcym zewnętrzem (Rybczyński 1996, s. 114-124), ale i indywidualnej satysfakcji czerpanej z przebywania w oswojonej, własnej, wypełnionej Ja przestrzeni.

Ten drugi sposób rozumienia domowej prywatności upowszechnił się później. Jak pisał o XVIII wieku Ariès: „To nie indywidualizm triumfował, lecz rodzina". Początkiem indywidualizacji przestrzeni domowej był wprowadzony pod koniec tego wieku zwyczaj coraz ściślejszego podziału pomieszczeń $z$ punktu widzenia ich funkcji, w tym urządzanie osobnych sypialni (Kałwa 2004 , s. 255). Istotny był też proces wyodrębniania jednofunkcyjnych pomieszczeń. We wcześniejszych epokach funkcje pomieszczeń bywały płynne, o czym świadczył zwyczaj nazywania ich kolorem obicia ścian. Zamiast mówić o sypialni czy jadalni, używało się nazw: pokój zielony, niebieski, biały (Kałwa 2004, s. 254). Kuchnia, miejsce, w którym koncentrowało się życie rodziny wiejskiej i małomiasteczkowej, w zamożnych kamienicach została oddzielona od części mieszkalnej i umieszczona w oficynach lub na tyłach domu; we dworach szlacheckich kuchnie mieściły się nawet w osobnych budynkach (Ferenc 2004, s. 147). Coraz ściślejszy podział funkcji pomieszczeń stał się tematem żartu dla Ignacego Krasickiego, który w Żonie modnej napisał:

„[...] Proszę, mospanie, do swoich pokojów.

Ja muszę mieć osobne od spania, od strojów,

Od książek, od muzyki, od zabaw prywatnych

Dla panien pokojowych, dla służebnic płatnych". 
Ostatni wers dotyczy pomieszczeń dla służby i wskazuje, że w tamtym czasie służba oddaliła się od centrum życia rodzinnego, przeniesiono ją do pomieszczeń gospodarskich i wzywano dzwonkiem, kiedy zaszła taka potrzeba (Ariès 1995, s. 451). Sam fakt posiadania służby na stałe kłóci się z dzisiejszym rozumieniem prywatności i intymności; trudno nam wyobrazić sobie, jak można było czuć się komfortowo stale mając na sobie wzrok obcych osób, jednak wówczas traktowano je jako niewidzialne. Ze współczesnego punktu widzenia ważne było wydzielenie dla nich osobnych pomieszczeń. Ogólnie wprowadzono wówczas oddzielenie $\mathrm{w}$ przestrzeni domowej służby od rodziny, dzieci od rodziców, a wśród dzieci i służby — separację ze względu na płeć. Proces ten można także interpretować jako stopniowe wyostrzanie systemów klasyfikacyjnych, charakterystyczne dla nowoczesności. Także ta tendencja najbardziej charakterystyczna była dla Anglii. Podczas gdy piękne dziewiętnastowieczne paryskie mieszkania ze względu na swoją elegancję były przedmiotem zazdrości w Niemczech i Austrii, w Anglii wypowiadano się o nich z lekceważeniem; uważano, że paryskie mieszkania są za małe i przepełnione, i nie pozwalają na separację mieszkańców oraz dyferencjację funkcji charakterystyczną dla domów angielskich (Madanipour 2003, s. 78).

Ogólnie owe tendencje do zachowania prywatności, zarówno w kontekście rodzinnym jak i osobistym, odnosiły się do wyższych warstw społecznych. Jeszcze w XX wieku we Francji w uboższych rodzinach nie istniało pojęcie intymności w domu. Sypiano często w jednym pomieszczeniu, nierzadko w jednym łóżku. „Moralność nie cierpi na tym, że wszyscy lub prawie wszyscy mieszkańcy śpią w jednym pomieszczeniu — pisał w 1894 r. Alfred de Foville w książce na temat domostw Les Maisons types. - Wręcz przeciwnie. Taka sytuacja sprawia, że wszyscy pilnują się nawzajem [...]. Cierpi na tym jedynie poczucie stosowności, ale skrępowanie jest znacznie mniejsze, niż sądzą ci, którzy nawykli do zajmowania oddzielnych pokoi" (zob. Prost 2000, s. 76-77). Prost dodaje, że na początku wieku we Francji w środowisku ludzi prostych jednostka nie dysponowała prawie żadnymi przedmiotami osobistymi prócz tych, które otrzymała w prezencie (na przykład scyzoryk, fajka, różaniec, zegarek). Druga połowa $\mathrm{XX}$ wieku to prawdziwa rewolucja: powstaje masowe budownictwo nowoczesnych mieszkań o większym metrażu i liczbie pomieszczeń, upowszechniają się urządzenia sanitarne i ogrzewanie, a czas pracy zostaje ograniczony do 40 godzin tygodniowo. Życie rodzinne zaczyna toczyć się wokół posiłków i ogranicza się do pokoju dziennego i jadalni bądź kuchni, a część czasu wolnego spędza się w przestrzeni osobistej. Dopiero więc wtedy przestrzeń domu ma trzy wymiary: publiczny, prywatny i osobisty (Prost 2000, s. 80).

Współcześnie możliwość „oswojenia” zamieszkiwanej przestrzeni i nacechowania jej rysami osobowości właściciela, czy też poczucie, że mieszkanie lub jego część są miejscem, w którym można „być sobą”, to ważny element poczucia komfortu. Prywatność zaś zyskuje znaczący walor. Potwierdzają to badania prowadzone przez Instytut Socjologii UAM w trzech wielkopolskich 
miejscowościach w latach 2005-2007 (Drozdowski, Krajewski 2008). Dotyczyły one społecznych wyobrażeń na temat szans oraz warunków kształtowania losu własnego i najbliższej rodziny oraz najbliższego otoczenia. Respondentów proszono między innymi o sfotografowanie i opis swojej przestrzeni domowej i okołodomowej oraz rozmaitych umieszczonych w niej przedmiotów. W ich wypowiedziach wielokrotnie pojawiały się wątki, które wskazywały na istotną rolę poczucia swojskości, prywatności, intymności czy też mieszkania lub jego części jako przestrzeni samorealizacji. Poczucie „bycia u siebie” kształtowane było na różne sposoby, na przykład przez własnoręczne wykonanie, modyfikowanie czy reperowanie przedmiotów. „Uwielbiam moją sypialnię - powiedziała jedna $z$ badanych — bo jest to miejsce osobiście przeze mnie wymyślone i wykonane. Ja ją tapetowałam i meblowałam. Jest to najsympatyczniejsze miejsce w moim domu". Taką funkcję ma też otoczenie się przedmiotami będącymi indeksami cech danej osoby lub istotnych ról społecznych, jakie pełni, albo po prostu przedmiotami umożliwiającymi wykonywanie lubianych czynności. „Cieszę się, że w tym małym mieszkaniu mam miejsce, gdzie mogę po prostu być" - mówi respondentka o swoim kąciku modlitewnym (fragmencie pokoju dziennego $z$ krucyfiksem na ścianie, roślinami i kanapa). Inna, uzasadniając konieczność remontu, stwierdza: „Ten pokój będzie chociaż w części w swym nowym kształcie określał moją osobę". W wypowiedziach badanych pojawiały się przedmioty związane $z$ hobby lub inną formą realizowania swoich zainteresowań albo też z pracą, na przykład atlas do ćwiczeń lub miejsce, w którym ustawiony jest komputerowy partner szachowy, minikancelaria domowa albo biurko $z$ komputerem. Komfortowe $\mathrm{w}$ tym przypadku jest poczucie, że przedmiot znajdujący się $\mathrm{w}$ domu został osobiście wybrany, wykonany lub nacechowany osobistym znaczeniem. Jego obecność jest dla jednostek źródłem satysfakcji czy dumy, elementem przywołującym wspomnienia bądź emocje i przede wszystkim środkiem służącym tworzeniu oswojonej, znajomej przestrzeni. Obcość przestrzeni zaś wynika, w świetle omawianych badań, $z$ istnienia takich obiektów, które - zaprojektowane czy zagospodarowane przez innych - stwarzają dysonans z punktu widzenia potrzeb czy preferencji jednostki. Mogą być to na przykład meble pozostawione przez poprzednich właścicieli. Ponadto uczucie dyskomfortu wywołują przedmioty sprzeczne $z$ wizją własnej osoby czy ujawniające nie lubiane w sobie cechy, na przykład rzeczy zepsute, których nie chce się naprawić czy zdjęcia ujawniające wstydliwe tajemnice.

Ważne dla poczucia komfortu są ponadto własne wzorce estetyczne i możliwość ekspresji gustu. Często chęć estetyzacji otoczenia przypisywano wyłącznie wyższym klasom (Bourdieu 2005), jednak tendencja do ozdabiania i upiększania przestrzeni cechuje także inne środowiska, choć dokonuje jej się przy użyciu innych środków. W badaniu prowadzonym przez Sebastiana Uretę (2007) okazało się, że mieszkańcy domów w dzielnicy robotniczej również dążą do estetycznej indywidualizacji otoczenia. Chociaż nabywają imitacje drogich przedmiotów i masowe dobra w tanich sklepach i na bazarach, są dumni z wła- 
snego pomysłu na ułożenie tych przedmiotów, który pokazuje ich wyjątkowość. Ponadto często zmieniają owe kompozycje dekoracyjne (nie mogąc pozwolić sobie na kupno nowych rzeczy, robią nowe aranżacje starych), a także indywidualizują przestrzeń za pomocą osobistych przedmiotów, takich jak pamiątki rodzinne, fotografie, dyplomy, przedmioty zrobione przez dzieci. Można przy tym stwierdzić, że wiele prób estetyzacji wnętrza jest jednak wyrazem znajomości pewnych estetycznych wzorów, czy to rodzinnych, czy medialnych, a wrażeniu bycia „niepowtarzalnym” często towarzyszy nieświadomość czerpania $z$ tych wzorów. W badaniach przeprowadzanych w 1975 r. w Krakowie i Skawinie Anna Rębowska (1982, s. 126-127) wykazała, że badani o najniższym poziomie wykształcenia powielali wiernie tradycyjne sposoby użytkowania mieszkań i drobnomieszczańskie wzory estetyczne, najczęściej żywiąc przekonanie, że osiągnięty efekt jest produktem ich własnej pomysłowości, a świadomość wykorzystywania pewnych wzorów, włącznie z sięganiem po literaturę fachową, pojawiała się wyłącznie u osób ze średnim i wyższym wykształceniem. We wspominanym wcześniej badaniu (Drozdowski, Krajewski 2008) estetyka mieszkań zamykała się w niewielkiej liczbie dość powtarzalnych schematów, a indywidualizowanie polegało raczej na „oswajaniu” przestrzeni za pomocą osobistych przedmiotów. Trzeba jednak przyznać, że mimo istnienia oczywistych wzorców dotyczących urządzania wnętrz, obecnie panuje bardzo duża dowolność w kształtowaniu miejsca zamieszkania.

Bardzo sugestywnym przykładem sytuacji braku prywatności uniemożliwiającej poczucie komfortu są mieszkania w hotelach robotniczych. Były to na ogół pomieszczenia dobrze wyposażone w podstawowe urządzenia i instalacje, lecz mieszkańcom najbardziej przeszkadzał, po pierwsze, brak prywatności, po drugie zaś - brak miejsca na przechowywanie przedmiotów osobistych. Lokatorzy nie mieli możliwości modyfikowania zastanej przestrzeni ani uczynienia jej swoją. Co więcej, sposób organizacji wnętrza narzucał pewne działania, ograniczał zaś inne. Umeblowanie pokoi krępowało ruchy i ograniczało wypoczynek. Sprzęty nie zapewniały ani wygody, a więc odpoczynku dla ciała, ani swobody poruszania się $\mathrm{w}$ przestrzeni. Wnętrza wypełnione były łóżkami lub tapczanami stojącymi pod ścianami, na środku stał stół i krzesła w liczbie stosownej do liczby mieszkańców. We wmurowanych szafach, oprócz ubrań, z braku innej możliwości przechowywane były produkty żywnościowe. Mieszkańcy w takim wnętrzu mieli do wyboru leżenie na łóżku, niekiedy piętrowym, bądź tapczanie, lub siedzenie na twardych krzesłach. Inny przykład sytuacji, w której brak komfortu wynika $z$ braku możliwości uprywatnienia przestrzeni znajdziemy w Historii życia prywatnego gdzie autorzy (Perrot, Guerrand 2006) pisali o starszych ludziach, skazanych na pobyt w hospicjum, gromadzących przedmioty gospodarstwa domowego i różne przybory kuchenne - ich jedyna wartość w tych warunkach polegała na tym, że nie były one częścią umeblowania ani wyposażenia hospicjum. Te należące do nich rzeczy, ich własne przedmioty, były więc synonimem domu". Osoba zamieszkująca hotel albo 
szpital cierpi bowiem na — jak powiedziałby Marek Krajewski (2008) — „specyficzną bezdomność polegającą na niemożliwości zadomowienia się w miejscu zamieszkania”. Przedmioty i przestrzenie, jak pisze dalej Krajewski, „stają się częścią nas nie tylko wtedy, gdy mamy prawo ich używać, ale o ile zostają powiązane z nami samymi, z naszą codziennością, ciałem, przyzwyczajeniami, czasowością". Obce miejsce, narzucające jednostce sposób organizacji czasu, do pewnego stopnia krępujące ruchy i zmuszające do układania ciała $\mathrm{w}$ inny sposób niż dotychczas, odbierające możliwość ekspresji siebie, swoich gustów i przyzwyczajeń, a także możliwość otoczenia się przedmiotami dającymi poczucie bezpieczeństwa i ciągłości, będące zaprzeczeniem prywatności, jest antytezą wnętrza komfortowego.

\section{WYGODA I FUNKCJONALNOŚĆ}

Obok szeroko rozumianej prywatności istotnym komponentem komfortu jest wygoda, a także funkcjonalność, rozumiana jako dogodność (ang. convenience), ale też ergonomia, oszczędność energii i łatwość obsługi. Oznacza to, że przedmioty albo układ, jaki one tworzą, zapewniają użytkownikom odpoczynek, przyjemność dla ciała. Jedna z respondentek Iana Woodwarda (2003, s. 403) w jego badaniu na temat mieszkań klasy średniej podsumowuje to następująco: „Nie kupiłabym antyków, bo większość jest bardzo niewygodna [...] ważne, aby krzesła były wygodne, te są bardzo proste, ale dobrze się na nich siedzi”, „ważna jest wygoda, położenie nóg na krześle”. Poczucie komfortu mieszkańcom mogą dać też obiekty, które niejako „ułatwiają” codzienne funkcjonowanie i pracę domową; dzięki swojej funkcjonalności, prostocie, łatwości obsługi, nie tylko skracają czas wykonywania czynności, ale i sprawiają, że uciążliwe obowiązki stają się przyjemne i proste. „Idealny dom? Praktyczny, łatwy do sprzątania, w którym łatwo się mieszka i wykonuje codzienne czynności" - wypowiada się respondentka Woodwarda (2003, s. 404). Komfort, jaki zapewnia przedmiot, to także podniesienie jakości czy wydajności pracy domowej i, co za tym idzie, zwiększenie ilości czasu wolnego oraz włączenie elementu przyjemności do codziennych czynności domowych. Dla niektórych takimi przedmiotami mogą być sprzęty elektroniczne w kuchni, redukujące pracę do wciśnięcia guzika, ale też telewizor, przy którym na przykład łatwiej i przyjemniej prasuje się lub szyje.

\section{Treść w miejsce formy}

Koncentracja na funkcjonalności i wygodzie bywa uznawana za przeciwieństwo koncentrowania się na pięknie czy formie. Zagadnienie to poruszał Pierre Bourdieu (2005) — skupienie się na formie przypisywał klasom wyższym, a na treści - niższym. Krytycznie podeszli do tej kwestii między innymi Sebastian Ureta (2007) i Ian Woodward (2003). W historii wystroju wnętrz, mówienie 
o funkcjonalności czy wygodzie początkowo również pojawiło się w opozycji do dyskursu piękna formy, miało dość rewolucyjny charakter i wiązało się z walką o tzw. nową architekturę. W rozwoju tego nowego dyskursu dużą rolę odegrali niemieccy architekci, tacy jak Alfred Loos, zwalczający „zbędną dekoracyjność” secesji i postulujący najprostsze układy, funkcjonalność, prawidłową konstrukcję, oraz Herman Muthesius, autor pracy „Dom angielski”, kierujący uwagę na kompozycję planu domu, racjonalne rozwiązania, oświetlenie (zob. Sienicki 1962, s. 257).

Jeden z polskich architektów, Julian Marchlewski pisał zaś w tym czasie:

„W użyciu są dziś meble najróżnorodniejszych stylów historycznych, przeważają styl Ludwika XIV, XV, styl cesarstwa, Restauracji i tzw. staroniemiecki. Każdy z nich niezawodnie jest piękny, jeśli zapatrywać się na te wyroby, jak na sprzęty muzealne, lecz żaden w czystej formie nie nadaje się do użytku dla nas, ludzi nowożytnych. [...] A jakże śmiesznie na przykład wygląda wielka masywna szafa biblioteczna o formach gotyckich, obliczona na to, by w niej stały foliały oprawne w oślą skórę, kiedy umieści w niej człowiek nowożytny swoje ozdobne wydania klasyków w miniaturowej formie i perkalowych oprawach złoconych. Nie mniej zabawnie wygląda sam właściciel, siedząc w kusej bonżurce na fotelu à la Luter, przed biurkiem wyglądającym jak mała forteca. Gwoli więc stylowi wzięliśmy na siebie komizm i niewygodę $\mathrm{w}$ dodatku, bo niewygodne są wszystkie sprzęty stylowe [...]. Charakter naszych mieszkań i tryb życia, a po części upodobania, wymagają sprzętów o rozmiarach nie mamutowych, lecz skromnych, sprzętów, lekkich, łatwo przenośnych" (cyt. za: Sienicki 1962, s. 255).

Funkcjonalność połączona z minimalizmem na przełomie XIX i XX wieku stawała się synonimem tego, co komfortowe; nowoczesne projektowanie coraz bardziej brało pod uwagę dopasowanie formy do funkcji przedmiotu, a mieszkania były „oczyszczane” ze zbędnych elementów dekoracyjnych i ciężkich mebli. Ta nowa definicja komfortu wyznaczyła też nowy styl estetyczny. W Polsce spółdzielnia artystyczna „Ład” wprowadzała modę na skandynawskie, proste, drewniane meble i przestronność, schludność wnętrz. Nie znaczy to jednak, że styl ten przyjął się powszechnie. W drobnomieszczańskich i robotniczych domach symbolem awansu i aspiracji, a także konserwatyzmu estetycznego, był zniekształcony mieszczański styl biedermeier (Kałwa 2004, s. 257). Meble produkowano jednak coraz bardziej masowo i coraz częściej rezygnowano $z$ dekoracyjności na rzecz funkcjonalności i wygody. Do dotychczasowego wyobrażenia komfortu doszła tym samym kolejna warstwa znaczeniowa. Już nie tylko piękny, wygodny, modny, swobodny, prywatny i swój - teraz dom powinien być również praktyczny.

Również ekonomia zmieniła podejście do materialnego otoczenia człowieka. Obok znanych już dyskursów dotyczących luksusu (ocenianego pejoratywnie jako zepsucie charakteru, ale jednocześnie uznawanego za rzadko kwestionowany przywilej arystokracji) i konieczności (wynikającej z biedy) pojawił się nowy sposób mówienia o materialności - jako wygodzie, dogod- 
ności, udogodnieniu, co zdaniem Johna E. Crowleya (1999) wyraża angielskie słowo convenience, będące poprzednikiem słowa comfort. Można sądzić, że wygoda czy dogodność - jako coś pomiędzy luksusem a koniecznością — stała się symbolem klasy średniej. Redefinicja pojęć konieczności i luksusu była związana, zdaniem Crowleya, $z$ nowymi trendami $w$ ekonomii, a więc kryzysem merkantylizmu i rozwojem liberalizmu, a tym samym $z$ uznaniem krajowej konsumpcji, a nie tylko importu i eksportu, za siłę napędową gospodarki, docenieniem jej roli we wzroście gospodarczym, co z kolei stało się moralnym uzasadnieniem konsumpcji, dało jej sens i uprawomocniało nabywanie dóbr. Dobra, które dawniej były zarezerwowane dla bogatych, teraz mogły nabywać także klasy średnie, między innymi dzięki możliwości uzasadnienia konsumpcji tych dóbr „wygodą”, „praktycznością” czy wręcz „przyzwoitością”. Nowy wizerunek luksusowych dawniej dóbr wspomogła ich dogodna cena, niższa ze względu na nowe, wydajne metody produkcji. Zdaniem Adama Smitha, kultura komfortu sprawiła, że obiekty dawniej prestiżowe stały się po prostu użyteczne i wygodne na co dzień i zaczęły być w powszechnym użyciu w różnych klasach społecznych. Do luksusu prawo miała arystokracja, do wygody przyznawano je każdemu: „wygodne domy, przyzwoite meble, ogień w zimie i ładny ogród latem, wystarczająco pieniędzy, by wychować dzieci. To uważam za potrzebny człowiekowi komfort, do którego nawet skromni nie muszą się wstydzić, i bez których niełatwo jest żyć" (Crowley 1999, s. 767). Co więcej, ideologia modernizmu wygodę włączyła do apeli o społeczną sprawiedliwość dla grup biednych i uciskanych. Bardzo popularne były humanitarne ruchy reformatorskie, które nakazywały, by wczuć się w sytuację innych i dać im prawo do komfortu. Nawet w więziennictwie nastąpiła reforma, pod wpływem pism Johna Howarda, który przedstawiał straszne więzienne warunki i żądał prawa więźniów do ogrzewania, wody i odpowiedniej cyrkulacji powietrza, parlament brytyjski wydał ustawę o zachowaniu zdrowia więźniów (Crowley 1999, s. 777). Reformatorzy użalali się też nad losem niewolników w Stanach Zjednoczonych. Inspektor budowlany Nathaniel Kent i architekt John Wood zaprojektowali w owym czasie modelowy dom w filantropijnym budownictwie, uważano bowiem, że należy zapewnić biednym godziwe warunki bytowania (Crowley 1999, s. 39). Pojawiające się $\mathrm{w}$ architekturze kwestie socjalne znalazły swoje miejsce w wydanej w 1933 r. Karcie Ateńskiej: „[...] architektura musi wrócić znowu na służbę człowieka, musi porzucić ideowy pompieryzm, musi pochylić się nad jednostką i tworzyć dla niej urządzenia, które będą określać i ułatwiać jej życie..." głosiło opracowanie przygotowane podczas Międzynarodowego Kongresu Architektury Nowoczesnej (Sołoducha, www.sztuka-architektury.pl).

Nauka, technologia, profesjonalizacja

Próby rozpowszechniania nowych modernistycznych koncepcji - niesienia „kaganka komfortu” — znalazły też odzwierciedlenie w nowych poradni- 
kach dotyczących urządzania domu, które radziły kierować się praktycznością, oszczędnością i dbałością o wygodę, czyli ideałami funkcjonalizmu (Kowecka 1975 , s. 245). Ruchom reformatorskim przyświecał nie tylko moralny imperatyw „każdy ma prawo do wygodnego życia”, ale i chęć wdrożenia w życie na szeroką skalę koncepcji naukowych dotyczących udoskonalenia mieszkania i pracy domowej, i uczynienia ich komfortowymi. $Z$ jednej strony były to koncepcje dotyczące higieny, związane między innymi z odkryciami medycyny i epidemiologii, $z$ drugiej zaś - idee racjonalizatorskie mające na celu wprowadzenie do domu zasad ergonomii, związane nie tylko z nowymi odkryciami naukowymi, ale uwarunkowane przez nowe technologie.

Istotnym składnikiem pojęcia komfortu jest higiena - podejście nowe w stosunku do istniejących wcześniej koncepcji czystości, które w znaczący sposób wpłynęło zarówno na postrzeganie tego, czym jest czyste wnętrze, jak i na praktyki utrzymywania czystości, a także propagowanie środków chemicznych i urządzeń służących do eliminacji brudu i kurzu, a tym samym - groźnych bakterii przyczyniających się do rozwoju chorób. Istotne dla historii domowego komfortu było uznanie wody za bron $\mathrm{w}$ walce $\mathrm{z}$ bakteriami, co pociągnęło za sobą stworzenie sieci hydraulicznych i doprowadzenie wody do mieszkań. Ponieważ woda w mieszkaniu długo była dobrem luksusowym, a dostęp do niejprzywilejem niewielu, było to oczywiste pole zróżnicowania społecznego (niższe klasy definiowane jako cuchnące). Ruchy reformatorskie, w tym na przykład ruchy misjonarskie, miały na celu zaszczepienie praktyk higienicznych i dyscypliny czystości wśród biednych i w koloniach, a tym samym wyzwolenie great unwashed (Shove 2003, s. 88-89). Uważano wówczas, że reforma higieniczna jest krokiem do zniwelowania podziałów społecznych. Koncepcje czystości przekładano na obywatelską dumę i społeczne dobre samopoczucie, uzasadniały one i legitymizowały inwestycje $\mathrm{w}$ kolektywne czyszczenie, na przykład w urządzenia sanitarne. Higiena była traktowana jako obowiązek moralny; nieprzestrzeganie jej zasad zagrażało publicznemu porządkowi (na przykład przez wybuch epidemii), a powszechne propagowanie tego obowiązku doprowadziło do normalizacji nowych kryteriów czystości i sposobów ich wdrażania.

$\mathrm{Na}$ wytworzenie i ustabilizowanie kryteriów czystości miało też wpływ wprowadzenie nowych technologii. Światło elektryczne rozświetliło mroczne dotąd izby, a urządzenia czyszczące, takie jak pralka i odkurzacz, podnosiły standardy czystości i zintensyfikowały potrzebę perfekcyjnego prowadzenia domu. Pytanie zatem, czy urządzenia te oszczędzały pracę, czy też ją mnożyły. W każdym razie wpłynęły na rozumienie pojęcia komfortu, a ich upowszechnianie uzasadniano zarówno oszczędnością czasu, jak i wysiłku włożonego w prace domowe, a poza tym możliwością uprzyjemnienia czynności domowych.

W kwestie domowego komfortu zaangażowanych było coraz więcej ekspertów: lekarze, technologowie, uczeni i praktycy. Wydawano wiele wspominanych już poradników dla gospodyń domowych. Na przykład Christene Frederick pokazywała, jak przez odpowiednie rozplanowanie kuchni można zmniej- 
szyć liczbę wykonywanych kroków i ilość marnowanej energii, a Lillian Gilbreth, jak zastosować w kuchni zasady tayloryzmu (zob. Hollows 2008, s. 27) Idee te były popularyzowane także przez czasopisma kobiece. Czytelniczki zachęcano do używania wiedzy naukowej, biznesowej i medycznej. Reklama Grape Nuts Company w magazynie kobiecym z 1928 r. głosiła na przykład: „Nowoczesna matka - bardziej niż ktokolwiek inny - jest w rodzinie ekspertem do spraw zdrowia”, a magazyn "The Business of Good Housekeeping” pokazywał, że rola żony w zarządzaniu domowym budżetem może być analogiczna do roli mężczyzn w sferze profesjonalnego biznesu i że da się prowadzić gospodarstwo domowe jak przedsiębiorstwo, wydając pieniądze „mądrze i naukowo" (szerzej zob. Hollows 2008, s. 28).

Poradniki dotyczące prowadzenia gospodarstwa domowego upowszechniały uznawaną wizję dobrego zamieszkiwania, to znaczy opierały się na wypracowanych „naukowo”, profesjonalnych i obiektywnych miarach komfortu, posiłkując się takimi terminami, jak higiena, funkcjonalność, ergonomia, optymalizacja, wygoda, zdrowie (zob. np. podręcznik szkolny Zajęcia w gospodarstwie domowym dla dziewczat — Przeradowski 1963). Kazimiera Pyszkowska w podręczniku z 1974 r. przypomina nawet o naukowych tradycjach będących podstawą zasad właściwego funkcjonowania domu:

Zasad organizacji pracy można się nauczyć. Nauka o organizacji pracy zajmuje się sprawnym i skutecznym działaniem ludzi, czyli takim, które najszybciej prowadzi do celu. [...] Już w XIX wieku amerykański inżynier Fryderyk Taylor opracował dla potrzeb przemysłu ciężkiego wzorzec pracy robotnika [...] wyeliminował ruchy zbędne i opracował szczegółowe instrukcje usprawniające metody i techniki pracy [...]. W Polsce naukę o organizacji pracy zapoczątkował Karol Adamiecki, który pierwszy wprowadził wykreśloną metodę planowania pracy przy pomocy harmonogramów" (Pyszkowska 1974, s. 328).

W poradniku autorstwa Wiesława Wieczorkiewicza z 1979 r. znajdziemy zaś między innymi schemat przedstawiający właściwe i niewłaściwe rozmieszczenie urządzeń w kuchni (s. 15), który ma zaoszczędzić polskiej gospodyni nawet do kilkunastu zbędnych kilometrów pokonywanych dziennie w kuchni przy przygotowywaniu posiłków. Rysunki przedstawiają „ciąg komunikacyjny” zorganizowany według kolejności „cyklów produkcyjnych” (mycie — obieranie — krojenie - formowanie - wkładanie do naczyń - przyrządzanie - podawanie - zmywanie). Kolejne ryciny instruują, jak prawidłowo rozmieszczać żywność i sprzęty kuchenne w szafkach, jakie są prawidłowe wymiary mebli, gdzie należy umieścić stół jadalny. W Polsce wydano wiele takich poradników, lansujących peerelowski model „nowoczesnej kobiety pracującej” (zob. np. Gumowska 1955; Janicka 1971; Dzięgielewska 1982; Kempista, Włostowska 1988).

Dziś istnieje zarówno poradnictwo książkowe, jak i w postaci programów telewizyjnych, takich jak „Perfekcyjna Pani Domu”, emitowany przez TVN Style, w którym ekspertka Anthea Turner w każdym odcinku przez dwa dni uczy dwie osoby zasad prowadzenia gospodarstwa domowego, a pod koniec tygo- 
dnia odwiedza uczestników programu, aby sprawdzić czy skorzystali z jej lekcji i poprawili wygląd swoich domostw. Wtedy rozstrzyga, który z jej uczniów okazał się najlepszy i zasłużył na miano najlepszej pani domu lub najlepszego pana domu" (Dudzisz 2007). Tego typu programów jest bardzo wiele, między innymi „Clean Sweep”, „Mission Organization”, „Clean House”, „Your New House”, „Extreme Makeover Home Edition”. Do grona domowych ekspertów dołączyła profesja „domowych organizatorek”, które „ramię w ramię z projektantami wnętrz i firmami budowlanymi zaprowadzają ład w spienionym morzu gratów kotłującym się w niejednym amerykańskim domu" (Bosacka 2009). Zawód ten istnieje w Stanach Zjednoczonych od lat osiemdziesiątych, a w ciągu ostatnich pięciu lat liczba wykonujących go osób wzrosła $z$ dwóch do blisko pięciu tysięcy.

Istnieje tendencja do naukowego i obiektywnego traktowania także innych aspektów komfortu. Badania naukowe na temat fizjologii ciała wpływają na przykład na sposób, w jaki projektuje się urządzenia regulujące temperaturę i wilgotność powietrza. Tym samym fizjologia pozwoliła uczynić z komfortu pojęcie uniwersalnie dostępne i definiowalne, podobnie jak naukowa definicja normalności. Wypracowane zostały standardy obowiązujące w wielu krajach na świecie. Wciąż jednak istnieją ogromne różnice w tym, co ludzie uważają za przyjemne wnętrze. We współczesnych biurach, urzędach i sklepach część ludzi dobrze czuje się przy działającej klimatyzacji, część zaś uważa ją za nieprzyjemną i źle wpływającą na ich samopoczucie. Istnieją kulturowe, grupowe, indywidualne zróżnicowania w sposobach rozumienia tego, co dla ludzi komfortowe.

W badaniu przeprowadzonym przez wielkie przedsiębiorstwo farmaceutyczne Merck zapytano ponad dwa tysiące ludzi o ich stosunek do miejsca pracy (Rybczyński 1996, s. 227). Pytania dotyczyły wystroju wnętrza, bezpieczeństwa, wydajności. Niezadowolenie pracowników najczęściej wywoływały nieodpowiednie oświetlenie i temperatura, a przecież te dwa czynniki były całkowicie kontrolowane, dostosowane do powszechnie obowiązujących standardów wypracowanych przez lekarzy i naukowców. Podobnie było, gdy jeden $z$ architektów przyjął założenie: „(nas) tam żadne socjo- czy psychologie nie interesują, bo dobry architekt potrafi w każdych warunkach zaprojektować dobre mieszkanie" (zob. Rębowska 1990, s. 158) - do zaprojektowanych przez niego mieszkań, mimo większego metrażu, nie chciały się przeprowadzać wielodzietne rodziny, które najwyraźniej przyjmowały inne kryteria dobrego wnętrza.

Interesujące wyniki przyniosły też badania przeprowadzone w latach dziewięćdziesiątych w Poznaniu i Gnieźnie w osiedlach substandardowych, gdzie brakowało kanalizacji i innych obiektywnych wskaźników dobrego mieszkania. Okazuje się, że mieszkańcy tych osiedli zapytani o to, co zrobiliby w sytuacji możliwości przeprowadzki, w większości nie chcieliby zmieniać miejsca zamieszkania. Dla nich zamieszkiwane domy spełniały kryteria komfortu czy „domowości”. Czy w takim razie możemy powiedzieć, że pojęcie komfortu 
jest całkowicie subiektywne? Raczej nie. Wydaje się, że zarówno standardy estetyczne, jak i pojęcie prywatności, czy koncepcja tego, co sprawia przyjemność lub ułatwia odpoczynek, w dużym stopniu stanowi kulturowe i rodzinne dziedzictwo, a w drugiej kolejności wynika z pewnych indywidualnych zróżnicowań, a także biologicznie i fizycznie uwarunkowanego odczucia komfortu i dyskomfortu.

\section{Opór czy adaptacja}

„Co ja sobie w domu zrobię, to jest moje. Tego mi żaden szef nie zreorganizuje. I za to ja odpowiadam. Zrobimy w domu co źle, to jest nasza wina. Poprawimy, zrobimy lepiej. Nikt nam tego nie podzieli ani nie połączy z czym innym, żeby po jakimś czasie znów dzielić i nazwać to reorganizacją".

$z$ wywiadu $z$ respondentem $z$ Katowic (Markowska 1990, s. 202)

Wynalazki naukowe i techniczne, które w założeniu mają ułatwić i uprzyjemnić pracę wszystkich, niekiedy $\mathrm{w}$ takim stopniu naruszają ustalony rytm codziennych czynności, że ich upowszechnienie napotyka spore bariery. Tak było na przykład ze zmywarką, wynalezioną w latach osiemdziesiątych XIX wieku przez Josephine Cochrane, żonę wpływowego amerykańskiego polityka, zmuszoną do wydawania mnóstwa przyjęć i zirytowaną faktem, że jej służba tłukła zbyt wiele naczyń. Pani Cochrane nigdy nie zmywała sama, uważając to za „czynność niegodną damy”, myślała też, że tak samo sądzą wszystkie Amerykanki. „Tymczasem, jak wykazały badania przeprowadzone na zlecenie zarządu fabryki zmywarek w 1915, Amerykanki nie miały nic przeciwko zmywaniu, więcej nawet - uważały, że znakomicie się przy tym wypoczywa po trudach dnia" (Panati 2004, s. 94-95). Zmywarki długo musiały czekać na popularność; dopiero w latach pięćdziesiątych zeszłego stulecia weszły w Stanach Zjednoczonych do powszechnego użytku, co było związane ze zmianą stylu życia i obyczajowości, przede wszystkim z emancypacją kobiet. Do dzisiaj jednak nie są obecne w każdym gospodarstwie domowym, nie tylko ze względu na cenę, ale na fakt, że dla wielu osób czynność zmywania za bardzo wrosła w rytm codzienności, stanowi element domowości.

Nowszego przykładu dostarczają wspominane już badania Anny Rębowskiej (1982). Jednym z badanych gospodarstw domowych było mieszkanie rodziny robotniczej, która zajmowała około trzydziestometrowy pokój oraz niewielkie pomieszczenie pomocnicze, wygospodarowane z części korytarza, wyposażone jedynie w kran, zlew i dwupalnikową kuchenkę oraz wannę bez odpływu. Choć możliwe było wydzielenie z pokoju dwu pomieszczeń, sypialni i pokoju dziennego, i pozostawienie pomieszczenia pomocniczego jako miejsca przygotowywania posiłków i mycia się, rodzina zdecydowaną część dnia spędzała w zaimprowizowanej „kuchni”, całkowicie pozbawionej światła dziennego. Pokój pełnił bowiem rolę odświętnej „białej izby” — przestrzeni reprezentacyjnej i nie używanej na co dzień. Wzór organizacji mieszkania według 
podziału na „czarną” i „białą” izbę okazał się zbyt trwały, by zmienił go zastany układ przestrzenny, w bardzo wysokim stopniu utrudniający odtwarzanie wyuczonego kodu zamieszkiwania. Starano się go zachować nawet kosztem zdrowia (respondentka zwierzyła się: „Straciłam częściowo wzrok przez pracę w ciemniej kuchni"; Rębowska 1982, s. 118). Rębowska pisze ponadto, że zdarzało się, iż realizowanie przyjętych wzorów wyzwalało konflikty. Na przykład dwuosobowa rodzina robotnicza ze wsi, dysponująca około trzydziestometrowym pomieszczeniem, aby zaspokoić potrzebę posiadania zarówno „czarnej”, jak i „białej” izby, zaanektowała wspólną kuchnię, w wyniku czego nowi współlokatorzy zmuszeni byli gotować posiłki dla trojga swoich dzieci w oddalonej i grożącej zawaleniem się oficynie.

Przykładem historycznym są badania opisywane przez Elizabeth Cohen (zob. Hollows 2008, s. 24), która pokazuje, w jaki sposób mieszkańcy wywodzący się ze środowisk robotniczych Ameryki końca XIX wieku podeszli do „właściwych” form mieszkania zaproponowanych im przez reformatorów z klasy średniej. Kuchnie, które w założeniu miały być miejscem pracy, robotnicy i tak traktowali jako miejsce spotkań. Choć $\mathrm{w}$ założeniu miało być higienicznie i prosto (bez tapicerki i pluszu), wprowadzili miękkie meble, kojarzące się im z domowością. Choć nowocześni reformatorzy społeczni optowali za prostymi, żelaznymi łóżkami, mieszkańcy chcieli zachować swoje ozdobne łoża, bo to wyobrażało $\mathrm{w}$ ich mniemaniu rodzinne szczęście.

Opór wobec nowych wzorów i kodów nie oznacza oczywiście, że relacje $z$ obiektami nigdy nie ulegają zmianom. Przeciwnie, pojawienie się w gospodarstwach domowych lodówki, telewizora czy klimatyzacji znacząco wpłynęło na zmiany w organizacji domowych czynności i przyzwyczajeń mieszkańców. Na przykład sposób ogrzewania i oświetlenia mieszkania miał wpływ na zintegrowanie lub, przeciwnie, rozproszenie członków rodziny po całym domu. Jedyne w domu palenisko czy świeca na stole były obiektami łączącymi domowników, którzy koncentrowali się wokół cennego źródła ciepła czy światła. Centralne ogrzewanie natomiast pozwoliło domownikom rozpierzchnąć się po mieszkaniu, umożliwiło prywatność, a ograniczyło wspólnotowy charakter organizacji przestrzeni życia domowników. Telewizor z kolei miał „na nowo złączyć rodzinę", przynajmniej początkowo. Przyjemność, jaką niosło z sobą oglądanie telewizji, skoncentrowała domowników wokół odbiornika i ograniczyła wychodzenie $z$ domu. Podobną rolę spełniły urządzenia klimatyzacyjne. W Ameryce ze zbyt wysoką temperaturą radzono sobie dawniej budując ocienione werandy na zewnątrz domu. Sprzyjały one upublicznieniu przestrzeni domowej, interakcjom z sąsiadami i przechodniami. Jednocześnie nie chroniły przed upałem w tym stopniu, by zatrzymać rodzinę w domu. Dopiero klimatyzacja zapewniła komfort nieporównywalny z przebywaniem na zewnątrz, tym samym zniechęcając mieszkańców do wychodzenia z domu (Shove 2003).

Na zmianę organizacji życia domowego może mieć wpływ zastany układ przestrzenny. Na przykład budowane w Polsce w latach sześćdziesiątych miesz- 
kania, z ich układem przestrzennym, metrażem i wielkością i kształtem poszczególnych pomieszczeń oraz absolutna dominacja meblościanki (por. Brosz 2005) miały wpływ na wytworzenie utrzymującego się potem przez lata wzoru urządzania domu i zamieszkiwania. Wpływ miały również poradniki i książki popularyzatorskie oraz wystawy i pokazy wnętrz, podczas których lansowano "meble-kombajny” i meblościanki, „z czasem rozbudowujące się w zabudowę całych ścian w formie regału ciężkiego" (Jarząbek 1982, s. 218). Popularyzowane wówczas zasady ekonomiki przestrzeni i ergonomii (w latach sześćdziesiątych przeniesiono na teren mieszkania niektóre zasady ergonometrii ekonomii ruchów - istotne zwłaszcza w odniesieniu do prac domowych, zasięgów, minimalnych odległości, nie uwzględniono jednak potrzeby swobody ruchu w mieszkaniu) „przeszły w nawyk jako swoiste horror vacui, jako tendencja do wypełniania przestrzeni, zamykania przestrzeni” (Jarząbek 1982, s. 218).

Ogólnie można powiedzieć, że chociaż nowe produkty i technologie zmieniają sposób myślenia o komfortowym mieszkaniu i mają wpływ na ukształtowanie się nowych wzorów działania, skrajny funkcjonalizm, polegający na uznawaniu komfortu za obiektywną, mierzalną kategorię, jest skazany na niepowodzenie, nie uwzględnia bowiem złożoności zjawiska. Zafascynowany tą koncepcją Le Corbusier poszedł jeszcze dalej, nie tyle podporządkowując formę funkcji, ale postulując całkowitą, ostentacyjną rezygnację $z$ formy na rzecz funkcji. Twierdził, że „dom jest maszyną do mieszkania”, proponował chłodne, fabryczne wnętrza, na których wyposażenie składały się konstrukcje z metalowych rurek, słoiki zamiast wazonów i reflektory zamiast lamp (Rybczyński 1998, s. 190). Funkcjonalność została zapewniona, uwzględniono oświetlenie, ciepło i przyrządy do pracy, jednak kosztem całkowitej rezygnacji z jakiegokolwiek zdobnictwa. Corbusier wychodził z założenia, że komfort jest czymś uniwersalnym, powszechnym, obiektywnym, uznawanym przez każdego. Nie wziął pod uwagę, że są ludzie, którzy efektywniej pracują w przestrzeniach obiektywnie niepraktycznych, ponieważ czują się tam dobrze. I że owo dobre samopoczucie jest kwestią bardzo złożoną, zależną od wielu czynników i niekoniecznie możliwą do przewidzenia. „Maszyna do mieszkania” Corbuseira - pisze Anna Rębowska (1990, s. 158) — „zawierała w sobie mechanicystyczną wizję człowieka, ograniczenie potrzeb do biologicznych, a zignorowanie tych związanych ze społeczną naturą człowieka i tradycją kulturową. Projekty przez niego realizowane okazywały się fiaskiem — nikt nie chciał tam mieszkać".

Komfort jest pojęciem niełatwym do zdefiniowania. Jego koncepcja jest złożona i kształtowała się pod wpływem wielu czynników - zmian technologicznych, rozwoju naukowego, narodzin i ewolucji społeczeństwa kapi- 
talistycznego oraz procesów modernizacyjnych. Najogólniej można określić komfort jako zadowolenie wynikające ze specyficznych relacji człowieka z otoczeniem, ale dokładniejsze stwierdzenie, co składa się na to zadowolenie, uwzględniać musi, obok obiektywnych czynników, takich jak dopasowanie przedmiotu do kształtu ludzkiego ciała, czynniki kulturowe, wyobrażenia ludzi żyjących w określonym miejscu i czasie o tym, co stanowi dobre wnętrze, a także czynniki indywidualne, subiektywne przekonania czy przyzwyczajenia.

\section{BIBLIOGRAFIA}

Ariès Philippe, 1995, Historia dzieciństwa: dziecko i rodzina $w$ dawnych czasach, tłum. Maryna Ochab, Marabut, Gdańsk.

Attfield Judy, 2006, Bringing Modernity Home: Open Plan in the British Domestic Interior, w: Irene Cieraad (red.), At Home: An Anthropology of Domestic Space, Syracuse University Press, Syracuse-New York.

Baydar Gülsüng, 2005, Figures of Woman in Contemporary Architectural Discourse, w: Hilde Heynen, Gülsüng Baydar (red.), Negotiating Domesticity: Spatial Productions of Gender in Modern Architecture, Routledge, London-New York.

Benedyktowicz Danuta, 1990, Struktura symboliczna domu, w: Piotr Łukasiewicz, Andrzej Siciński, Dom we wspótczesnej Polsce, Wiedza o Kulturze, Wrocław.

Bosacka Katarzyna, 2009, Akcja Organizacja, „Gazeta Wyborcza”, dodatek „Wysokie Obcasy", nr 53 (506).

Bourdieu Pierre, 2005, Dystynkcja. Społeczna krytyka władzy sądzenia, tłum. Piotr Biłos, Scholar, Warszawa.

Chapman Tony, Hockey Jeremy (red.), 1999, Ideal Homes? Social Change and Domestic Life, Routledge, London-New York.

Cieraad Irene (red.), 2006, At Home: An Anthropology of Domestic Space, Syracuse University Press, Syracuse-New York.

Crowley John E., 1999, The Sensibility of Comfort, „The American Historical Review”, t. 104, s. $749-782$.

De Mare Heidi, 2006, Domesticity in Dispute: A Reconsideration of Sources, w: Irene Cieraad (red.), At Home: An Anthropology of Domestic Space, Syracuse University Press, Syracuse-New York.

Drozdowski Rafał, Krajewski Marek (red.), 2008, Wyobraźnia spoteczna. Horyzonty - źródła - dynamika. Uwarunkowania strategii dostosowawczych wspótczesnego spoteczeństwa polskiego. Studium socjologiczne, Wydawnictwo Naukowe UAM, Poznań.

Duby Georges (red.), 1998, Historia życia prywatnego, t. 2, tłum. różni, Ossolineum, Wrocław.

Edensor Tim, 2004, Tożsamość narodowa, kultura popularna $i$ życie codzienne, tłum. Agata Sadza, Wydawnictwo UJ, Kraków.

Ferenc Marek, 2004, Czasy nowożytne, w: Andrzej Chwalba (red.), Obyczaje w Polsce, Wydawnictwo Naukowe PWN, Warszawa.

Górska Anna, Szperlich Ewa, 1985, Model mieszkania w opiniach rodzin, „Prace i Materiały IWP", z. 94, Warszawa. 
Heynen Hilde, 2005, Modernity and Domesticity: Tensions and Contradictions, w: Hilde Heynen, Gülsüng Baydar (red.), Negotiating Domesticity: Spatial Productions of Gender in Modern Architecture, Routledge, London-New York.

Hollows Joanne, 2008, Domestic Cultures, Open University Press, London-New York.

Jarząbek Zdzisława, 1982, Kultura mieszkaniowa $w$ nowych osiedlach wielkomiejskich, w: Ewa Kaltenberg-Kwiatkowska (red.), Mieszkanie — analiza socjologiczna, Państwowe Wydawnictwo Ekonomiczne, Warszawa.

Kaltenberg-Kwiatkowska Ewa (red.), 1982, Mieszkanie - analiza socjologiczna, Państwowe Wydawnictwo Ekonomiczne, Warszawa.

Kałwa Dobrochna, 2004, Polska doby rozbiorów i międzywojnia, w: Andrzej Chwalba (red.), Obyczaje w Polsce, Wydawnictwo Naukowe PWN, Warszawa.

Korczak Lidia, 2004, Wieki średnie, w: Andrzej Chwalba (red.), Obyczaje w Polsce, Wydawnictwo Naukowe PWN, Warszawa.

Kowecka Elżbieta, 1975, Poradnictwo mieszkaniowe w XIX wieku, w: Mirosława Gajewska i in., Dom $i$ mieszkanie $w$ Polsce. Druga potowa XVII-XIX w., Ossolineum, Wrocław.

Krajewski Marek, 2008, Motywy przewodnie i przedmioty, w: Rafał Drozdowski, Marek Krajewski (red.), Wyobraźnia społeczna. Horyzonty —źródła - dynamika. Uwarunkowania strategii dostosowawczych wspótczesnego społeczeństwa polskiego. Studium socjologiczne, Wydawnictwo Naukowe UAM, Poznań.

Laermans Rudi, Meulders Carine, 2006, The Domestication of Laundering, w: Irene Cieraad (red.), At Home: An Anthropology of Domestic Space, Syracuse University Press, Syracuse-New York.

Łukasiewicz Piotr, Siciński Andrzej (red.), 1990, Dom we wspótczesnej Polsce, Wiedza o Kulturze, Wrocław.

Madanipour Ali, 2003, Public and Private Spaces of the City, Routledge, New York.

Madigan Ruth, Munro Moira, 1996, „House Beautiful”: Style and Consumption in the Home, „Sociology”, t. 30, s. 41-57.

Maldonado Thomas, 1996, The Idea of Comfort, w: Victor Margolin, Richard Buchanan (red.), The Idea of Design, MIT Press, Cambridge, MA.

Markowska Danuta, 1990, Dom - twierdza tożsamości, w: Piotr Łukasiewicz, Andrzej Siciński, Dom we wspótczesnej Polsce, Wiedza o Kulturze, Wrocław.

Miks-Rudkowska Nina, 1975, Wnętrza mieszkalne $w$ miastach polskich $w$ drugiej potowie XVII $i$ w XVIII wieku, w: Mirosława Gajewska i in., Dom i mieszkanie w Polsce. Druga połowa XVII-XIX w., Ossolineum, Wrocław.

Miller Lane Barbara (red.), 2007, Housing and Dwelling: Perspectives on Modern Domestic Architecture, Routledge, London-New York.

Munro Moira, Madigan Ruth, 2006, Negotiating Space in the Family Home, w: Irene Cieraad (red.), At Home: An Anthropology of Domestic Space, Syracuse University Press, Syracuse-New York.

Panati Charles, 2004, Niezwykłe dzieje zwykłych rzeczy, tłum. Grzegorz Woźniak, Ossolineum, Wrocław.

Perrot Michelle, Guerrand Roger Henri, 2006, Sceny i miejsca, w: Historia życia prywatnego, t. 4, Ossolineum, Wrocław.

Prost Antoine (red.), 2000, Historia życia prywatnego, t 5: Od I wojny światowej do naszych czasów, Ossolineum, Wrocław. 
Rębowska Anna, 1982, Użytkowanie mieszkań - gospodarka przestrzenia, w: Ewa Kaltenberg-Kwiatkowska (red.), Mieszkanie — analiza socjologiczna, Państwowe Wydawnictwo Ekonomiczne, Warszawa.

Rębowska Anna, 1990, Funkcje i typy domu w oczach architekta i socjologa, w: Piotr Łukasiewicz, Andrzej Siciński, Dom we wspótczesnej Polsce, Wiedza o Kulturze, Wrocław.

Rice Charles, 2007, The Emergence of the Interior: Architecture, Modernity, Domesticity, Routledge, London-New York.

Ruszało Monika, 2008, Domność, „Artpapier”, nr 11.

Rybczyński Witold, 1996, Dom. Krótka historia idei, tłum. Krystyna Husarska, Marabut, Warszawa.

Shove Elizabeth, 2003, Comfort, Cleanliness and Convenience: The Social Organization of Normality, Berg, Oxford-New York.

Shove Elizabeth, 2006, Constructing Home: A Crossroads of Choices, w: Irene Cieraad (red.), At Home: An Anthropology of Domestic Space, Syracuse University Press, Syracuse-New York.

Sienicki Stefan, 1962, Wnętrza mieszkalne. Rys historyczny, Arkady, Warszawa.

Starkey David, 2006, Monarchy: From the Middle Ages to Modernity, HarperCollins Publishers, London.

Ureta Sebastian, 2007, Domesticating Homes: Material Transformation and Decoration Among Low-income Families in Santiago, Chile, „Home Cultures”, t. 4, s. 311-336.

Van Herck Karina, 2005, „Only Where Comfort Ends, Does Humanity Begin”: On the „Coldness” of Avant-Garde Architecture in the Weimar Period, w: Hilde Heynen, Gülsüng Baydar (red.), Negotiating Domesticity: Spatial Productions of Gender in Modern Architecture, Routledge, London-New York.

Woodward Ian, 2003, Divergent Narratives in the Imagining of the Home amongst Middle-Class Consumers: Aesthetics, Comfort and the Symbolic Boundaries of Self, "Journal of Sociology", t. 39, s. 391-412.

Zadrożyńska Anna, 1990, Ludzie i przestrzeń domowa - przyczynek do antropologii schronienia, w: Piotr Łukasiewicz, Andrzej Siciński, Dom we wspótczesnej Polsce, Wiedza o Kulturze, Wrocław.

Dudisz Aleksandra, Perfekcyjna pani domu, www.dom.kobiety.net.pl/60,0,Perfekcyjnapani-domu,793.html [05.02.2009].

Sołoducha Krzysztof, Krótka historia blokowisk, www.sztuka-architektury.pl/index.php? ID_PAGE $=258$ [27.05. 2008].

\section{Poradniki}

Dzięgielewska Z., 1982, ABC porządków domowych, Warszawa.

Gumowska I., 1955, My i nasz dom, Warszawa.

Janicka M., 1971, Mój dom, Warszawa.

Kempista J., Włostowska J., 1988, Porady praktyczne z zakresu gospodarstwa domowego, Szepietowo.

Przeradowski J., 1963, Zajęcia w gospodarstwie domowym (dla dziewczat), Warszawa.

Pyszkowska K., 1974, Gospodarstwo domowe. Zajęcia praktyczno-techniczne dla dziewczat, Warszawa.

Wieczorkiewicz W., 1979, Poradnik dla użytkowników mieszkań, Warszawa. 
COMFORT, OR WHAT LIVING WELL MEANS

\section{Summary}

The article considers comfort in the home, that is the feeling that the place in which one lives and the manner in which things are organized within that space are for the individual a source of satisfaction and allow them to feel "at home". The background to the analysis of the modern understanding of comfort is the historical processes of the formation of such categories as individuality, cosiness, comfort and functionality. In the discussions are utilized the results of recent studies in Poland and abroad of domestic lifestyles.

\section{Key words/słowa kluczowe}

comfort / komfort, habitation / zamieszkiwanie, private space / przestrzeń prywatna, everyday life / życie codzienne, history of everyday life / historia życia codziennego 